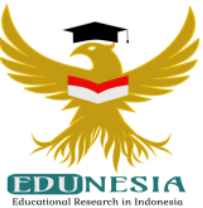

\title{
Application of Inquiry Learning Model to Increase Motivation and Learning Outcomes of Grade IX Students at MTsN 3 West Aceh
}

\author{
Eddy N Mustika \\ Science Education, MTsN 3 Aceh Barat, Indonesia \\ Corresponding Email: eddynmustika@gmail.com, Phone Number : 0813 xxxx xxxx
}

Article History:
Received: Feb 16, 2021
Revised: Mar 19, 2021
Accepted: Mar 27, 2021
Online First: Mar 31, 2021

Keywords:

Inquiry, Learning outcomes, Motivation.

\section{Kata Kunci:}

Hasil belajar, Inkuiri, Motivasi.

\section{How to cite:}

Mustika, E.N. (2021). Application of Inquiry Learning Model to Increase Motivation and Learning Outcomes of Grade IX Students at MTsN 3 West Aceh. Edunesia: Jurnal Ilmiah Pendidikan, 2 (2): 444-451.

This is an open access article under the $C C-B Y-N C-N D$ license

\begin{abstract}
This study aims to obtain a description of teacher activity, in the process of this research is motivated by the low motivation and value of student learning outcomes, this is marked by $78.95 \%$ student scores still have not reached the minimum completeness criteria. This research is aimed at the use of the inquiry method in science grade IX-A learning on electromagnetic induction material. The research method used is classroom action research. The subjects of this study were 38 students of grade IX-A semester 2 MTsN 3 West Aceh, consisting of 16 male and 22 female students. Data collection techniques with tests, observation and documentation. The results of research using the inquiry method in the learning process increase the motivation and learning outcomes of students. The initial condition was $18 \%$ or 7 students increased to 21 students or $55 \%$ and reached $100 \%$ from $85 \%$, and the increase in student learning outcomes from the average in the initial condition was 55.79, increasing to 65.79 in cycle I and on the end of the second cycle increased to 79.21 and completeness of learning in the initial conditions as many as 8 students $(21.05 \%)$. Based on the results of the research, it can be concluded that learning using the inquiry method can improve the process, motivation and learning outcomes of grade IX-A students at MTsN 3 West Aceh Semester 2 Academic Year 2020/2021 on learning science with electromagnetic induction material.
\end{abstract}

Abstrak: Penelitian ini bertujuan memperoleh gambaran aktivitas guru, dalam proses penelitian ini dilatarbelakangi oleh rendahnya motivasi dan nilai hasil belajar siswa, hal ini di tandai dengan 78,95\% nilai siswa masih belum mencapai kriteria ketuntasan minimal. Penelitian ini ditujukan pada penggunaan metode inkuiri dalam pembelajaran IPA Kelas IX A pada materi induksi elektromagnetik. Metode penelitian yang digunakan adalah penelitian tindakan kelas. Subjek penelitian ini adalah siswa Kelas IX A semester 2 MTsN 3 Aceh Barat yang berjumlah 38 siswa terdiri dari siswa laki-laki 16 siswa dan perempuan 22 siswa. Teknik pengumpulan data dengan tes, observasi dan dokumentasi. Hasil penelitian menggunakan metode inkuiri dalam proses pembelajaran membuat motivasi dan hasil belajar siswa mengalami peningkatan. Kondisi awal sebesar $18 \%$ atau 7 siswa meningkat menjadi 21 siswa atau 55\% dan mencapai angka 100\% dari $85 \%$, dan peningkatan hasil belajar siswa dari rata-rata pada kondisi awal sebesar 55,79 meningkat menjadi 65,79 pada siklus I dan pada akhir siklus II meningkat menjadi 79,21 serta ketuntasan belajar pada kondisi awal sebanyak 8 siswa (21,05\%). Berdasarkan hasil penelitian di atas dapat disimpulkan bahwa pembelajaran dengan menggunakan metode inkuiri dapat meningkatkan proses, motivasi dan hasil belajar siswa Kelas IX A MTsN 3 Aceh Barat Semester 2 Tahun Pelajaran 2020/2021 pada pembelajaran IPA dengan materi induksi elektromagnetik. 


\section{A. Introduction}

Education is not only the responsibility of students and educators but parents, society, government so that active participation is needed from the parties concerned. According to Ara and Imam (2012) education is a conscious and planned effort to create an atmosphere of learning process so that students actively develop their potential to have religious spiritual strength, self-control, personality, intelligence, noble character, and the abilities they need. society, nation and state. Students get education through a learning process organized and designed by the teacher. Prawira (2012) suggest that learning is an active process that needs to be stimulated and guided towards the desired results. Based on the 2013 curriculum, natural science is one of the sciences that relates to how to find out about nature systematically, so that science is the result of human activities in the form of knowledge, ideas and concepts oriented about the natural environment, which is obtained from the experience of a series of scientific processes, including investigation, preparation and testing of ideas so that they can help students gain direct experience to develop their competences in order to be able to study and understand the natural surroundings scientifically.

The decrease in enthusiasm for learning can be caused by several factors. Apart from being caused by methodological inaccuracies, it is also rooted in the conventional paradigm which always applies conventional and teacher-centered learning methods. The fact is that there is a structural space divider that is so high between teachers and students. As mentioned by Trianto (2011), what happens most often in the field is the lack of motivation of students so that they are less participating, less involved, and students do not have initiative and are contributive both intellectually and emotionally. Students tend to be passive when participating in teaching and learning activities. Questions from students, ideas or opinions of students rarely appear. Even if there is an opinion that appears it is very rarely followed by other ideas as a response. Every teacher has a desire that what is taught to students is easy to understand. However, the fact is that students find it difficult to understand if they do not see directly the object being studied. In the eyes of natural sciences requires two kinds of competences, namely competence in understanding concepts and competence in scientific work. According to Gusniwati (2015) concept understanding is the ability to find abstract ideas in mathematics to classify objects that are usually expressed in a term and then poured into examples and not examples, so that someone can understand a concept clearly. Meanwhile, according to Yunuka (2016) conceptual understanding is the ability to behave, think and act shown by students in understanding definitions, understanding of special features, the essence and content of mathematics and the ability to choose the right procedures in solving problems. Meanwhile, scientific work competence is a process skill that includes inferring and selecting various ways or procedures that include the simplest abilities, namely observing, measuring up to the highest ability, namely the ability to experiment. So far, the enthusiasm of students in taking science lessons at school is not like following other lessons. Students think that science is a rote lesson so their motivation to be enthusiastic about this subject is often considered trivial. For students, science concepts and principles are easy to understand at home and seem boring. This has an impact on students' low interest in learning science. This problem is one of the classic problems that teachers often encounter in schools. Dislike of science lessons can also have an impact on students' attitudes towards their teachers. Not a few teachers get less sympathy from their students because of the students' failure to learn science. Poor scores on formative and summative science tests place teachers as the cause of failure in the eyes of students and 
parents. Students' attitudes will be very different to arts or sports teachers, for example, subjects that are favorite for most students. The reality that occurs in the field is that the learning outcomes of students IX-A MTsN 3 West Aceh in science learning are still low. This is evidenced by the scores in the pre-cycle activities held at IX-A MTsN 3 West Aceh on electromagnetic induction material obtained by 16 out of 20 students or $80 \%$ who still scored below the minimum completeness criteria and the remaining 4 students or around $20 \%$ have reached a value above the minimum completeness criteria, which is 70 .

Still not optimal student learning outcomes can be caused by several factors, one of which in science learning is still just material or an explanation from the teacher so that students are not trained to be able to look for problems and solve them on their own, students are expected only to understand concepts without experimenting to find facts and findings. of the concepts that have been taught. This situation has a negative impact which can cause the motivation and learning outcomes of students IX-A MTsN 3 West Aceh to be low. In accordance with the rationale and facts above, it can be concluded that there is still a lack of quality in science learning, so it is necessary to solve these problems. The solution to this problem is to apply inquiry modeled learning. Majid (2013) explains another name for inquiry learning, namely heuristics which comes from the Greek heurisk which means I found. Inquiry learning emphasizes critical and analytical thinking processes to seek and find their own answers to a questionable problem. According to Sanjaya (2011) inquiry learning strategy is a series of learning activities that emphasize critical and analytical thinking processes for finding and find yourself a definite answer to a question in question. This thought process can be carried out through investigations and experiments. While the guided inquiry learning model is an inquiry learning model where the teacher still plays a role in helping the learning process, so that students are not just let go. Agree with this Marera (Sujarwo, 2011) argues that inquiry learning can help students analyze learning material by creating a varied learning atmosphere so that students are motivated to learn optimally in increasing curiosity. Meanwhile, Wena (2010) explains that in general, the principle of inquiry is as follows: a) students will ask if they are faced with a problem that is confusing or unclear, b) students can realize and learn to analyze their thinking strategies, c) new thinking strategies can be taught directly and added to what they already have, and d) inquiry in groups can enrich the mind and help students learn about the temporary nature of knowledge and respect the opinions of others. The application of inquiry modeled learning is carried out by the teacher by guiding students to make use of the facilities in the school environment. This inquiry modeled learning was carried out as an effort to increase motivation and science learning outcomes of grade IX-A students at MTsN 3 West Aceh. One of the advantages of the inquiry learning model is that it can increase student motivation and learning outcomes. This is because students are given the opportunity to seek and find their own answers to problems given through observations and experiences from the students themselves (Rizema, 2013).

\section{B. Method}

The research method used was classroom action research which adapted the Kemmis \& Mc. Taggart with two cycles. The subjects of this study were 38 students of Class IX A semester 2 MTsN 3 West Aceh, consisting of 16 male and 22 female students. The technique of collecting data is by using test, observation and documentation techniques. The data validation used source triangulation and method triangulation techniques. The data analysis technique was processed by descriptive analysis. The implementation in each cycle 
is based on input from the previous cycle (Arikunto, 2013). The stages in this research in the form of an image diagram are as follows.

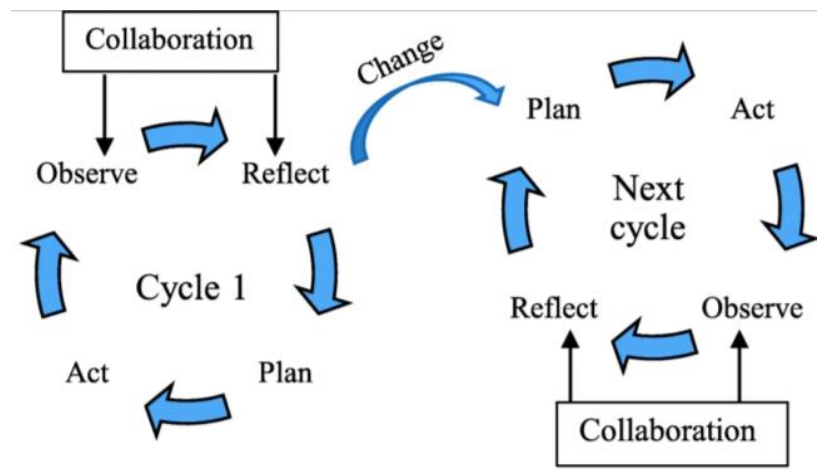

Figure 1. Implementation of action research

\section{Result and Discussion}

The use of the inquiry method will be very helpful in arousing student motivation, this is evident from the learning outcomes given in each cycle have increased. The recapitulation of students' formative test results from the initial conditions, cycle I to cycle II can be seen in the table below.

Table 1. Recapitulation of formative test value initial findings, cycle I and II

\begin{tabular}{llccccc}
\hline \multirow{2}{*}{ No } & \multirow{2}{*}{ Description } & \multirow{2}{*}{ Value } & \multicolumn{2}{c}{$\begin{array}{c}\text { Students Not } \\
\text { Completed }\end{array}$} & \multicolumn{2}{c}{ Students Completed } \\
\cline { 3 - 7 } & & & Frequency & $\%$ & Frequency & $\%$ \\
\hline 1 & Initial & 56,00 & 4 & 20,00 & 16 & 80,00 \\
2 & cycle I & 64,00 & 10 & 50,00 & 10 & 50,00 \\
3 & cycle II & 76,50 & 18 & 90,00 & 2 & 10,00 \\
\hline
\end{tabular}

To clarify the increase in student learning completeness and the decrease in student learning completeness can be seen in the bar chart below:

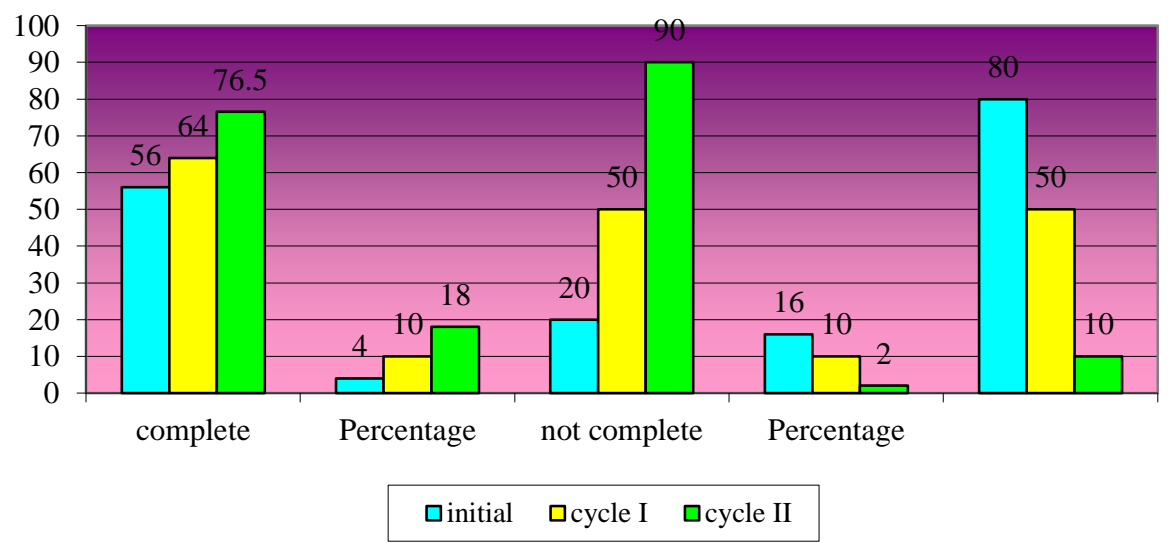

Figure 2. Graph of Increasing and Decreasing Students' Learning Completeness in Initial Study. 
It can be seen that before implementing learning improvements through the application of the inquiry method in science learning electromagnetic induction material, the number of students who completed learning in the initial state was 4 students $(20 \%)$, after improvements were made by the application of the inquiry method in cycle I increased. to 10 students or $50 \%$ and in cycle II it increased back to 18 students or $90 \%$. As for the explanation of the decline in students who have not completed their learning in the initial state as many as 16 students or $80 \%$, after improvements were made by the application of the inquiry method in cycle I decreased to 10 students or $50 \%$ and in cycle II decreased to 2 students or $10 \%$. The explanation of the increase in the average value of learning outcomes in science learning with the application of the inquiry method shows a significant increase in which the initial condition is 56.00, it increases to 64.00 in the first cycle and at the end of the second cycle it increases to 76.50. The increase in the average value of student learning outcomes in graphical form as shown below:

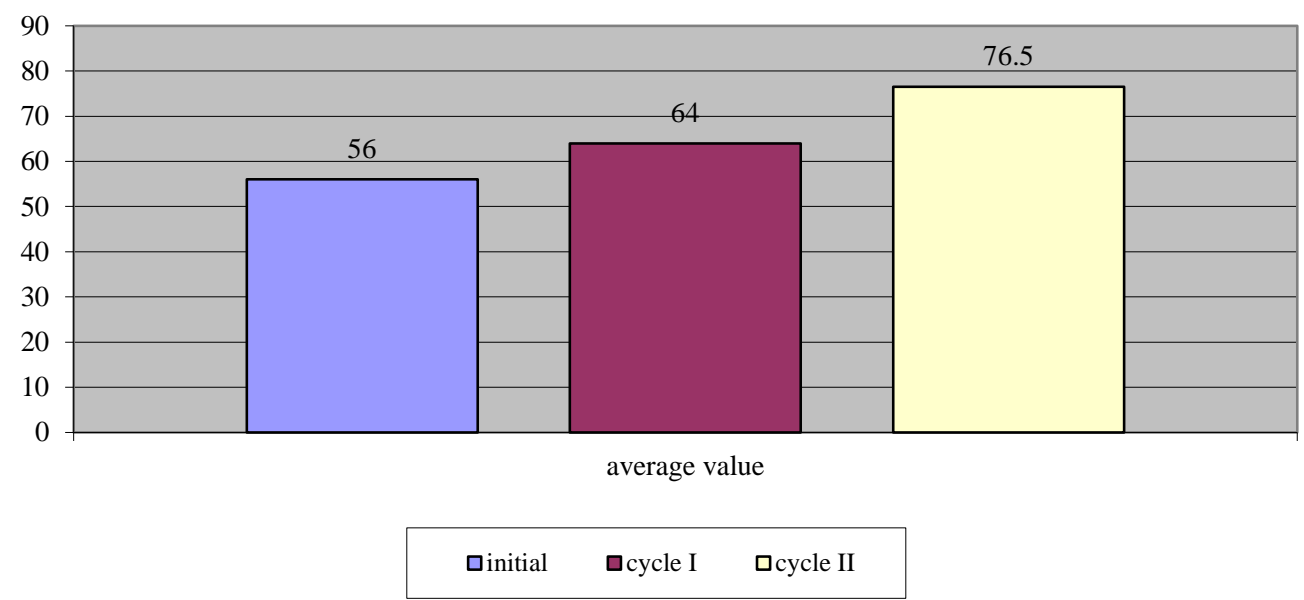

Figure 3. Graph of the average improvement of student learning outcomes in initial study

Cycle I and II The success of the learning improvement process is not only seen from the increase in learning achievement or formative test scores. Student motivation during the learning process is also an indicator of success in the learning process. Student motivation data were obtained from the observation sheets that had been filled in by the observer during the learning improvement. The focus of observation is focused on being diligent in facing tasks and resilient in facing difficulties, not requiring external encouragement to excel, wanting to explore the material or field of knowledge provided, always trying to achieve the best possible and showing interest in various problems. The results of observations on the implementation of learning improvement activities show positive results, and are proven by an increase in student motivation in each cycle. In detail, an explanation of increasing student motivation in the learning improvement process is as shown in the table below: 
Table 2. Recapitulation of increasing student motivation in cycle I and II

\begin{tabular}{llcccc}
\hline \multirow{2}{*}{ No } & \multirow{2}{*}{ Description } & \multicolumn{2}{c}{$\begin{array}{c}\text { Students Not } \\
\text { Completed }\end{array}$} & \multicolumn{2}{c}{ Students Completed } \\
\cline { 3 - 6 } & & Frequency & $\mathbf{\%}$ & Frequency & $\%$ \\
\hline 1 & Initial & 6 & 30 & 14 & 70 \\
2 & cycle I & 12 & 60 & 8 & 40 \\
3 & cycle II & 20 & 100 & 0 & 0 \\
\hline
\end{tabular}

It is clear that the increase in student motivation during the learning improvement process is as described in the picture below:

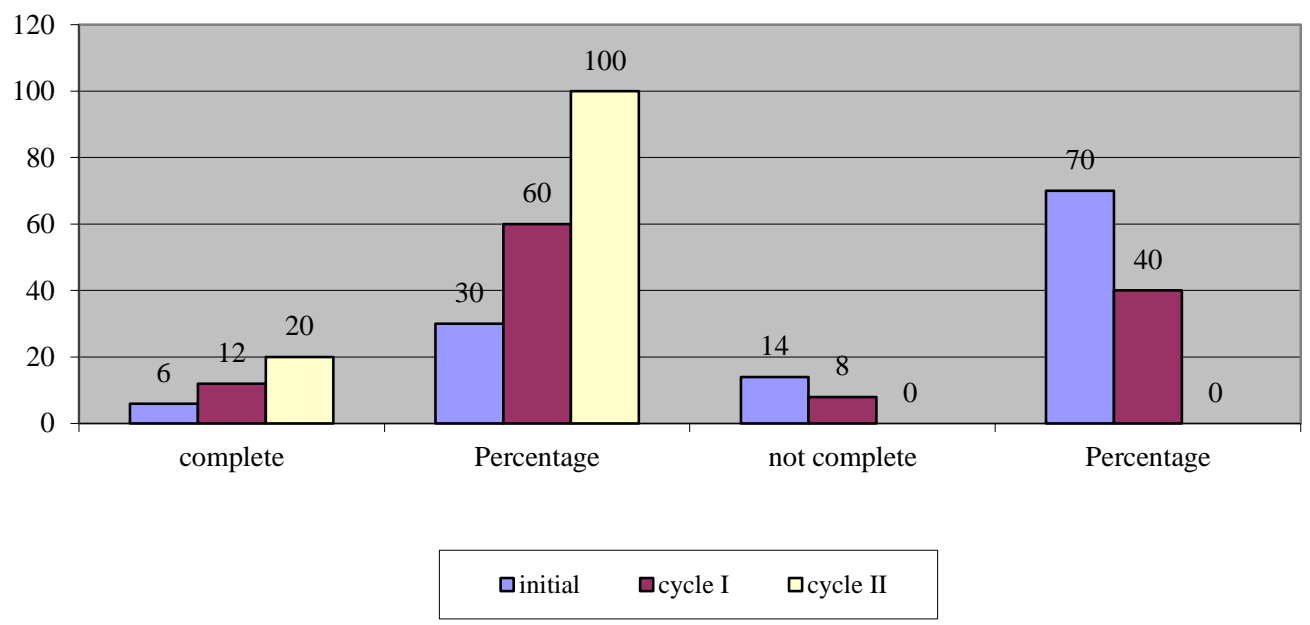

Figure 3. Graph of student completeness based on the level of student motivation

The results of observations regarding student motivation based on the success criteria of learning improvement, it can be concluded that the learning improvement process was declared successful because the increase in student motivation from the initial condition was $30 \%$ or 6 students increased to 12 students or $60 \%$ and reached $100 \%$ of the $85 \%$ minimum limit. which has been determined on the success criteria of the learning improvement process in the second cycle. The research that has been carried out in two cycles by applying electromagnetic induction learning using the inquiry method has been able to increase motivation and science learning outcomes of grade IX-A students of MTsN 3 West Aceh in the academic year 2020/2021 from initial conditions, cycle I to cycle II. This research focuses on natural Sciences subjects in the subject of electromagnetic induction. The purpose of this research is to improve, increase learning and develop the ability of students to face problems in learning in class, especially motivation and student learning outcomes. Before the learning process in cycle I, the writer made observations of the conventional teaching and learning process. This activity begins with an explanation of the material, giving examples, giving assignments, discussion then evaluation. Based on the pre-cycle activities that have been carried out, it can be seen that there are still many students who have not completed the learning process. It is proven that there are 4 students who are declared complete in the science learning process. Thus, the other 16 students were declared incomplete or scored below the minimum completeness criteria, namely 68 . From the results 
of previous observations, during learning students only listened and took notes. Student learning motivation is very low as evidenced by only 6 students or $30 \%$ who are declared complete assessed from their learning motivation. This is indicated by students rarely asking questions, let alone expressing their opinions. Their understanding of the material presented is very low because they do not experience themselves in finding and finding an answer to the problem at hand. As a result, students have difficulty when faced with a problem solving. From these results, it is necessary to take action so that student learning motivation increases. From the results of research in cycle I and cycle II, it shows that the method of learning with the inquiry method has a positive impact in increasing student motivation and learning outcomes. This can be seen from the increasing level of completeness and student learning outcomes in each cycle, only $4(20 \%)$ were complete but there was an increase in learning completeness in cycle I by $90 \%$ This was due to fun learning using the Inquiry learning model where students as learning subjects in groups were given the opportunity to solve their own problems with supporting media so that the teaching and learning process becomes more effective. The second cycle experienced completeness with a percentage of $90 \%$, this means that the value of 18 grade IX-A students experienced completeness and was in accordance with the minimum completeness criteria. This is also supported by an increase in student learning motivation where in the initial conditions it was $30 \%$ or 6 students increased to 12 students or $60 \%$ and reached $100 \%$ of the $85 \%$ minimum limit that had been determined in the success criteria for the learning improvement process in the second cycle. In accordance with the results of the researchers' reflection trying to make improvements, this time the students in the class were already familiar with learning using the inquiry method and were enthusiastically exploring their own understanding, besides that the researchers also presented material that was simpler and in accordance with the level of student understanding. Based on the results of the implementation of learning improvement data as described above in the form of data from the formative test results cycle I, cycle II formative tests and observation data from cycles I and II, it can be concluded that the application of the inquiry method can improve student learning outcomes in science learning in grade IX-A MTsN 3 West Aceh Academic Year 2020/2021.

\section{Conclusion}

Based on the results of data analysis, the results of research conducted in two cycles showed that: 1). The application of the inquiry learning model can improve the science learning process on electromagnetic induction material. This is evidenced by students increasingly asking questions and expressing their opinions. The understanding of the material presented also increases because they experience themselves in finding and finding an answer to the problem faced so that students do not experience difficulties when faced with a problem solving, 2). The application of the inquiry learning model can improve the learning outcomes and completeness of science learning students on electromagnetic induction material. This is evidenced by an increase in student learning motivation from the initial conditions of $30 \%$ or 6 students increasing to 12 students or $60 \%$ and reaching $100 \%$ of the $85 \%$ minimum limit that has been determined in the success criteria of the learning improvement process in the second cycle, and 3). The application of the inquiry learning model is able to improve the learning outcomes and mastery of science learning students on electromagnetic induction material. This is evidenced by the increase in student learning 
outcomes from an average in the initial conditions of 56.00 increased to 64.00 in the first cycle and at the end of the second cycle increased to 76.50 and learning completeness in the initial conditions was 4 students (20\%) After the improvement was carried out by the application of the inquiry method in the first cycle it increased to 10 students or $50 \%$ and in the second cycle it increased again to 18 students or $90 \%$.

\section{References}

Ara, H., \& Imam, M. (2012). Pengelolaan Pendidikan Konsep, Prinsip, dan Aplikasi dalam Mengelola Sekolah dan Madrasah. Bantul: Kaukaba.

Arikunto, S. (2013). Prosedur Penelitian: Suatu Pendekatan Praktik. Jakarta: Rineka Cipta.

Gusniwati, M. (2015). Pengaruh Kecerdasan Emosional Dan Minat Belajar Terhadap Penguasaan Konsep Matematika Siswa Sman Di Kecamatan Kebon Jeruk. Jurnal Formatif, 5(1): 26-41. Diakses pada 10 Oktober 2015 http://journal.lppmunindra.ac.id/index.php/Formatif/article/viewFile/165/158

Majid, A. (2013). Strategi Pembelajaran. Remaja Rosdakarya: Bandung.

Prawira, P.A. (2012). Psikologi Pendidikan dalam Perspektif Baru.Yogyakarta: AR-RUZZ MEDIA

Sanjaya. W. (2011). Kurikulum dan Pembelajaran Teori dan Praktik Pengembangan Kurikulum Tingkat Satuan Pendidikan (KTSP). Jakarta: Kencana Prenada Media Group.

Sujarwo. (2011). Model-Model Pembelajaran suatu Strategi Mengajar. Yogyakarta: Venus Gold Press.

Trianto. (2011). Panduan Lengkap Penelitian Tindakan Kelas Classroom Action Research Teori \& Praktik. Jakarta: Prestasi Pustaka Publisher.

Wena, M. (2010). Strategi Pembelajaran Inovatif Kontemporer Suatu Tinjauan Konseptual Operasional. Jakarta: Bumi Aksara.

Yunuka, L. (2016). Kemampuan Pemahaman Konsep Matematika Mahasiswa Melalui Penerapan Lembar Aktivitas Mahasiswa (LAM) Berbasis Teori Apos pada Materi Turunan. Universitas PGRI Palembang. Edumatica. Volume 06 Nomor 01 April ISSN 2088-2157 